\title{
PENGARUH PARTISIPASI MASYARAKAT DAN SISTEM KEUANGAN DESA (SISKEUDES) TERHADAP KEBERHASILAN PENGELOLAAN DANA DESA DI DESA KRASAK
}

\author{
The Influence Of Community Participation And Financial System \\ (Siskeudes) On The Success Of Village Fund Management In Krasak \\ Village Brebes Regency
}

\author{
Dewi Kartika \\ dewikartika563@gmail.com \\ Program Studi Akuntansi Politeknik Harapan Bersama \\ Jalan Mataram No.09 Pesurungan Kota Tegal \\ Krisdiyawati \\ krisdiyawati@poltektegal.ac.id \\ Program Studi Akuntansi Politeknik Harapan Bersama \\ Jalan Mataram No.09 Pesurungan Kota Tegal \\ Azarine Sava Vania Slamet \\ azarinesava@gmail.com \\ Program Studi Akuntansi Politeknik Harapan Bersama \\ Jalan Mataram No.09 Pesurungan Kota Tegal
}

\begin{abstract}
ABSTRAK
Penelitian mempunyai tujuan untuk mengetahui Partisipasi Masyarakat Dan Sistem Keuangan Desa Terhadap Keberhasilan Pengelolaan Dana Desa Di Desa Krasak Kabupaten Brebes. Metodologi penelitian melalui pengumpulan data dengan teknik survey kuesioner kepada responden dan pengambilan sampel mengunakan rumus slovin. Teknik analisis data dalam penelitian ini menggunakan analisis regresi linier berganda dengan menggunakan aplikasi SPSS versi 22. Hasil dari penelitian ini menunjukkan bahwa variabel partisipasi masyarakat berpengaruh signifikan secara parsial terhadap keberhasilan pengelolaan dana desa sedangkan variabel penggunaan sistem keuangan desa berpengaruh secara signifikan secara parsial terhadap keberhasilan pengelolaan dana desa dan partisipasi masyarakat dan sistem keuangan desa berpengaruh secara simultan terhadap keberhasilan pengelolaan dana desa.
\end{abstract}

Kata Kunci: Keberhasilan Pengelolaan Dana Desa, Partisipasi Masyarakat, Siskeudes.

\section{ABSTRACT}

This study aims to determine the Participation of The Village Community and Financial System to the Success of Village Fund Management in Krasak Village, Brebes Regency. Research methodology through data collection with questionnaire survey techniques to respondents and sampling using slovin formula. The data analysis 
techniquein this study used multiple linear regression analysis with the help of SPSS version 22. The results of this study showed that the variables of community participation had a partial significant effect on the success of village fund management, the variable use of the village financial system had a significant partial effect on the success of village fund management and community participation and the village financial system simultaneously influenced the success of village fund management

Keywords: Success of Village Fund Management, Community Participation, Siskeudes

\section{PENDAHULUAN}

Desa merupakan ujung tombak peningkatan masyarakat serta pembangunan desa yang ada dalam Undang-undang Nomor 6 Tahun 2014 tentang Desa. Wewenang yang diberikan desa untuk mensejahterakhan masyarakatnya untuk meningkatkan perekononomian desa dapat memberikan potensi yang baik. Setiap tahun pemerintah pusat telah mendanai serta menganggarkan dana untuk diberikan desa yang cukup besar. Menjadi desa yang berkembang dan mandiri dan unggul dan tidak menjadi desa yang tertinggal merupakan yang diharapkan Pemerintah Pusat.

Menurut Mulyanto (2015) Desa yang mumpuni dan berkembang serta menjadi desa yang professional merupakan upaya yang dilakukan pemerintah serta yang dianggarkan oleh pemerintah dengan menyiapkan tata kelola desa. Dengan adanya Undang-undang Nomor 6 Tahun 2014 tentang Desa, maka masyarakat maupun pemrintah mempunyai banyak harapan guna menjadi desa yang bermasyarakat yang sejahtera, karena harapan desa menjadi pemerintah desa yang berkualitas, unggul dan masyarakatnya sejahtera. Besarnya harapan tersebut membuat desa harus melakukan tata kelola dana desa dengan baik, jujur serta ekun ulet yang harus dilakukan peerintah desa apabila masih yang belum baik perlu pembenahan pun perlu dilakukan seperti misalnya, perbaikan sumber daya manusia, komitmen pemerintah desa terhadap pembangunan, dan lain-lain.

Menurut Adi (2007) Identifikasi masalah serta pasrtisipasi masysrakat desa dimasyarakat ada potensi serta menangani solusi dan alternatif menanganinya dalam keterlibatan, keikutsertaan serta keterlibatana tata kelola dan keputusan yang menjadi keterlibatan masyarakat dan perubahannya. Namun Teori agensi memberikan banyak gambaran bahwa seharusnya tentang aparatur desa (agent) serta masyarakat sebagai (principal) saling bekerja sama dalam, bergotong royong, rukun dalam pengelolaan dana desa. Siskeudes membantu mengomptimalkan, mewujudkan dan menjadikan Desa yang 
baik dan optimal itu merupakan salah satu cara aparatur desa memberikan pemahamana serta keputusan yang terbaik bagi masyarakat.

Aplikasi Sistem Keuangan Desa (Siskeudes) ialah aplikasi gratis untuk perencanaan serta pembuatan anggaran Desa, pembukuan, pencatatan dan pelaporan dana desa yang disediakan oleh Pemerintah. Baik Pemerintah kabupaten maupun kota juga dapat menggunakan Siskuedes guna mencatat serta membukukakn dan melaporkan Anggaran Pendapatan dan Belanja Daerah (APBDes) dan Laporan Realisasi APBDes yang dilaporkan ke semua desa. Dengan menggunakan aplikasi siskeudes tersebut, Kaur Keuangan tinggal memasukkan data penggunaan anggaran secara otomatis akan terhitung nilai pajak, lembar bendahara dan juga pembiayaan lain yang menyertai, maka penggunaan anggaran di desa lebih transparan dan dapat dipertanggungjawabkan sesuai aturan, Sehingga pencairan tahapan penyelesaian pekerjaan (termin) berikutnya cepat dan mudah

Sesuai dengan Peraturan Daerah Kabupaten Brebes Nomor 4 Tahun 2015 pasal 24 ayat 5 tentang Keuangan Desa yang menyatakan bahwa Pemerintah mengalokasikan Dana sesuai ketentuan yang berlaku dan Alokasi Dana Desa (ADD) juga sesuai ketentuan yang berlaku setiap tahunnya. Alokasi Dana Desa yang diberikan dimaksudkan guna mendukung dan membantu program-program dan kegiatan Pemerintah Desa dalam bidang penyelenggaraan pemerintahan, pembangunan desa, pembinaan kemasyarakatan desa dan pemberdayaan masyarakat yang ada di Desa.

Lomboh (2015) mengatakan bahwa partisipasi masyarakat sangat dibutuhkan untuk keberhasilan pembangunan di desa menuju ke arah yang lebih baik, peran dan kinerja pemerintahan desa juga sangat diharapkan untuk dapat menjalankan tugas pokok memimpin dan mengoordinasikan dalam melaksanakan urusan rumah tangga desa, melakukan pembinaan dan pembangunan masyarakat dan membina perekonomian desa.

Menurut Bupati Brebes Idza Priyanti jumlah dana desa yang diterima 292 desa di Kabupaten Brebes pada 2020 mengalami kenaikan Rp 54,6 miliar dibanding tahun 2019 Rp 441 miliar menjadi $\mathrm{Rp}$ 495,6 miliar, namun realisasi penggunaan dan desa tahun anggaran 2020 sampai saat ini sebesar Rp463.423.579.400 (Tribun jateng.com).

Besarnya jumlah dana yang ditransfer dari APBN (Anggaran Pendapatan dan Belanja Negara) menimbulkan kekhawatiran berbagai pihak karena rawan terjadi korupsi dan pengelolaan yang tidak efisien dan efektif. Karena bertambahnya alokasi dana desa tiap tahunnya tidak menjamin teresap nya seluruh dana desa yang diperoleh. Berdasarkan 
hal diatas maka sangatlah penting memberikan pemahaman untuk mengetahui tentang pengelolaan dana desa untuk masyarakat. Sehingga peneliti tertarik untuk mengkaji Pengaruh Partisipasi Masyarakat Dan Sistem Keuangan Desa Terhadap Keberhasilan Pengelolaan Dana Desa Di Desa Krasak Kabupaten Brebes.

\section{METODE PENELITIAN}

\section{Lokasi dan waktu Penelitian}

Penelitian ini dilakukan di wilayah Brebes yaitu Masyarakat Desa Krasak Brebes yang dilaksanakan pada Bulan April s.d Juli 2021.

\section{Populasi dan Sampel}

Berdasarkan Informasi Kepala Desa Krasak masyarakat Desa Krasak sejumlah 7.223. maka Populasi yang digunakan untuk penelitian ialah masyarakat Desa Krasak Kabupaten Brebes sejumlah 7.223.

Sampel penelitian ini dipilih dengan pendapat Slovin dengan rumus berikut:

Keterangan :

$$
\mathrm{n}=\frac{\mathrm{N}}{1+\mathrm{Ne}^{2}}
$$

$\mathrm{n}=$ Ukuran sampel

$\mathrm{N}=$ Populasi

e $=$ Tingkat ketepatan $10 \%$

maka perhitungan sampel sebagai berikut :

$$
\begin{array}{ll}
\mathrm{n}= & \frac{7.223}{1+7.223(10)^{2}} \\
\mathrm{n}= & \frac{7.223}{73,23} \\
\mathrm{n}= & 98,63=99
\end{array}
$$

Tabel 1. Perincian Sampel

\begin{tabular}{ccc}
\hline No & Keterangan & Jumlah \\
\hline 1 & Kuesioner yang disebar & 99 \\
2 & Kuesioner yang kembali & 99 \\
3 & Kuesioner tidak lengkap & 7 \\
4 & Kuesioner yang lengkap & 92 \\
\hline
\end{tabular}

Sumber : Data diolah, 2021 


\section{Jenis dan Sumber Data}

Jenis penelitian ini ialah penelitian deskriptif dengan metode survei kuesioner, wawancara dan diskusi terarah bersama masyarakat dengan pendekatan kualitatif dan kuantitatif.

Sumber Data penelitian menggunakan Data Primer. Data primer yang digunakan dalam penelitian ini seperti data yang dikumpulkan dari hasil penelitian berupa pembagian angket atau kuesioner melalui kepada warga Desa Krasak Brebes.

\section{Metode Analisis Data}

Metode analisis data yang digunakan peneliti dalam penelitian ini ialah Analisis Statistik Deskriptif, Uji Validitas, Uji Realibilitas, Uji Asumsi Klasik: Uji Normalitas, Uji Multikolinearitas, Uji Heterokedastisitas, Analisis Regresi Linier Berganda, Uji t, Uji F.

a. Analisis Statistik Deskriptif

Uji ini bertujuan guna memberi pendeskripsian atau penggambaran mengenai suatu data. Suliyanto (2011) mengemukakan statistik deskriptif terdiri atas penghitungan minimum, maksimum, mean, serta standar deviasi yang dimaksudkan guna memberikan penggambaran tentang perilaku dan distribusi data yang mempelajari penyajian dan penyusunan data yang telah terkumpul melalui suatu penelitian.

b. Uji Instrumen Data

\section{Uji Validitas}

Menurut Ghozali (2011) Uji validitas digunakan untuk mengukur sah atau valid tidaknya suatu kuesioner. Suatu kuesioner dikatakan valid jika pertanyaan pada kuesioner mampu untuk mengungkapkan sesuatu yang akan diukur oleh kuesioner tersebut (Ghozali, 2011).

2. Uji Realiabilitas

Menurut Ghozali (2011) Uji reliabilitas ialah suatu indeks yang menunjukkan sejauh mana hasil suatu penelitian pengukur dapat dipercaya. Secara umum suatu konstruk atau variabel dikatakan reliabel jika nilai Cronbach Alpha lebih besar dari 0,60 (Ghozali:2011).

c. Uji Asumsi Klasik

1. Uji Normalitas

Suliyanto (2011) mengemukakan pengujian ini dimaksudkan guna melakukan pengujian apakah nilai residual yang sudah terstandarisasi pada model 
regresinya berdistribusi normal atau tidak normal. Selain itu, pengujian ini memiliki tujuan guna melakukan pengujian apakah variable pengganggu atau residual pada model regresinya berdistribusi normal atau tidak. Teknik pengujian normalias distribusi data secara analitis menggunakan rumus Kolmogorov-Smirnov, dengan signifikansinya yaitu 5\% (Suliyanto, 2011).

2. Uji Multikolinearitas

Suliyanto (2011) mengartikan pengujian ini sebagai tidak adanya korelasi linier yang mendekati sempurna antar dua atau lebih variable independentnya. Dalam melakukan pendeteksian ada atau tidak adanya multikolinearitas, bisa menggunakan tolerance dan variance inflation factor (VIF). Menurut Suliyanto (2011), jika nilai tolerance $\leq 10$ berarti tidak ada multikolinearitas, sedangkan jika tolerance $>10$ berarti tidak ada multikolinearitas. Nilai tolerance yang digunakan dalam penelitian ini yaitu 0,10 .

\section{Uji Heteroskedastisitas}

Menurut Suliyanto (2011), pada pengujian ini terdapat varian variable dalam model regresinya yang tidak konstan atau tidak sama. Suatu model regresi dapat dikatakan baik apabila data yang digunakan bersifat homoskedastisitas atau tidak ada gejala heteroskedastisitas.

d. Analisis Regresi Linier Berganda

Menurut Suliyanto (2011) Analisis regresi berganda adalah analisis yang dipergunakan dalam melakukan prediksi satu variabel bergantuk pada dua atau lebih variabel independentnya, dalam menguji hipotesis persamaan satu menggunakan penganalisisan regresi linier berganda.

Dalam penelitian ini untuk melakukan pengujian terhadap pengaruh variabel independen (partisipasi masyarakat dan sistem keuangan desa) terhadap variabel dependen (keberhasilan pengelolaan dana desa) maka bisa disusun sebuah persamaan sebagai berikut

$$
\mathrm{Y}=\alpha+\mathrm{b}_{1} \mathrm{x}_{1}+\mathrm{b}_{2} \mathrm{x}_{2}+\mathrm{e}
$$

Keterangan :

$$
\begin{array}{ll}
\mathrm{Y} & =\text { Pengelolaan Dana Desa } \\
\mathrm{a} & =\text { Konstanta } \\
\mathrm{b} & =\text { Koefisien Regresi } \\
\mathrm{X}_{1} & =\text { Partisipasi Masyarakat }
\end{array}
$$




$$
\begin{array}{ll}
\mathrm{X}_{2} & =\text { Sistem Keuangan Desa } \\
\mathrm{e} & =\text { Error }
\end{array}
$$

\section{e. Uji t}

Pengujian ini memiliki tujuan guna mengukur pengaruh secara parsial atau individu variabel independent terhadap variabel dependennya. Analisis hasil uji t dilakukan sebanyak jumlah variabel independent yang dipergunakan pada suatu pengujian.

Dalam mengambil suatu keputusan uji t bisa dilakukan dengan 2 cara (Ghozali, 2013):

Dengan melakukan perbandingan terhadap $t_{\text {hitung }}$ dan $t_{\text {tabel }}$ :

1. Ho diterima jika $\mathrm{t}_{\text {hitung }}<\mathrm{t}_{\text {tabel }}$ pada $\alpha=5 \%$

2. Ho ditolak (Ha diterima), jika $t_{\text {hitung }}>t_{\text {tabel }}$ pada $\alpha=5 \%$

Dengan menggunakan angka signifikasi

1. Ho diterima jika signifikansinya $>0,05$

2. Ho ditolak (Ha diterima) jika signifikansinya $<0,05$

\section{f. Uji F}

Pengujian ini memiliki tujuan guna menguji variable independent terhadap variable dependennya secara stimulant atau bersama. Menurut Ghozalo (2013), dalam mengambil keputusan uji F bisa menggunakan 2 cara, yaitu:

Melakukan perbandingan terhadap $\mathrm{F}_{\text {hitung }}$ dan $\mathrm{F}_{\text {tabel }}$

1. Ho diterima apabila $\mathrm{F}_{\text {hitung }}<\mathrm{F}_{\text {tabel }}$ pada $\alpha=5 \%$

2. Ho ditolak (Ha diterima) apabila $\mathrm{F}_{\text {hitung }}>\mathrm{F}_{\text {tabel }}$ pada $\alpha=5 \%$

Dengan berdasarkan angka signifikasi

1. Ho diterima apabila signifikansinya $>0,05$

2. Ho ditolak (Ha diterima) apabila signifikansinya $<0,05$

\section{HASIL DAN PEMBAHASAN}

\section{Hasil Penelitian}

\section{a. Hasil Statistik Deskriptif}

Berdasarkan data dari 92 Masyarakat Desa Krasak melalui daftar pertanyaan yang di dapat kondisi responden tentang jenis kelamin dan usia dan pendidikan. Penggolongan yang dilakukan terhadap responden dalam penelitian ini bertujuan untuk mengetahui secara jelas mengenai objek penelitian tersebut satu persatu dapat diuraikan sebagai berikut : 
Berdasarkan hasil kuesioner yang disebarkan kepada masyarakat Desa Krasak sebanyak 92 orang, maka diperoleh data responden sebagai berikut :

Tabel 2. Hasil Uji Reliabilitas Seluruh Variabel

\begin{tabular}{ccc}
\hline \multicolumn{3}{c}{ Jenis Kelamin } \\
\hline Pria & Wanita & Total \\
33 & 59 & 92 \\
$35,9 \%$ & $64,1 \%$ & $100 \%$ \\
\hline
\end{tabular}

Sumber : Data diolah, 2021

Dari data diatas memperlihatkan bahwa masyarakat yang berjenis kelamin pria sejumlah $35,9 \%$ dan berjenis kelamin perempuan sejumlah $64,1 \%$ orang yang menjadi responden dalam penelitian ini

\section{b. Uji Instrumen data}

1. Hasil Uji Validitas

Uji validitas digunakan untuk mengukur sah atau valid tidaknya suatu kuesioner. Kriteria yang digunakan untuk menyatakan suatu instrumen dianggap valid atau layak digunakan dalam pengujian hipotesis apabila dalam uji validitas menunjukan nilai sig. < alpha 0,05 .

Tabel 3. Hasil Uji Validitas Seluruh Variabel

\begin{tabular}{lcc}
\hline \multicolumn{1}{c}{ Variabel } & Sig. (2-tailed) & Keterangan \\
& & \\
\hline Partisipasi Masyarakat 1 & 0,000 & Valid \\
Partisipasi Masyarakat 2 & 0,000 & Valid \\
Siskeudes 1 & 0,000 & Valid \\
Siskeudes 2 & 0,000 & Valid \\
Siskeudes 3 & 0,000 & Valid \\
Pengelolaan Dana Desa1 & 0,000 & Valid \\
Pengelolaan Dana Desa2 & 0,000 & Valid \\
Pengelolaan Dana Desa3 & 0,000 & Valid \\
\hline
\end{tabular}

Sumber : Data diolah, 2021

Berdasarkan hasil Uji Validitas variabel Partisipasi Masyarakat, Siskeudes dan Pengelolaan Dana Desa didapatkan besarnya nilai Sig. (2-tailed) dari semua butir pertanyaan variabel $<0,05$ hal ini menunjukkan bahwa data tersebut valid. 


\section{Hasil Uji Reliabilitas}

Ghozali (2011) menjelaskan bahwa uji reliabilitas ialah alat untuk mengukur suatu kuesioner yang merupakan indikator dari peubah atau konstruk. Butir kuesioner dikatakan reliabel (layak) jika cronbach's alpha $>0,60$

Tabel 4. Hasil Uji Reliabilitas Seluruh Variabel

\begin{tabular}{cc}
\hline Variabel & Cronbach's Alpha \\
\hline Partisipasi Masyarkat & 0,807 \\
Siskeudes & 0,667 \\
Pengelolaan Dana Desa & 0,814 \\
\hline Sumber : Data diolah, 2021
\end{tabular}

Berdasarkan hasil tabel 4 diatas hasil uji reliabilitas menjelaskan bahwa nilai Cronbach's Alpha pada variabel Partisipasi Masyarakat, Siskeudes serta Pengelolaan Dana Desa mencapai lebihdari 0,60 maka dapat disimpulkan bahwa variabel keseluruhan ialah reliabel.

\section{c. Hasil Uji Asumsi Klasik}

\section{Hasil Uji Normalitas}

Menurut Ghozali (2013), uji ini mempunyai tujuan guna mengukur apakah variable residual atau pengganggu pada model regresi terdistribusi normal atau tidak normal. Uji $t$ maupun uji f memberikan asumsi nilai residual terdistribusi normal, jika asumsi tersebut tidak sesuai berarti pengujian statistiknya dianggap tidak valid. Pengujian dengan statistik parametrik memiliki syarat utama yakni data penelitian harus terdistribusi normal. Uji normalitas data dipergunakan pada data residual model regresi menggunakan pengujian Kolmogorov Smirnov. Hasil pengujian Kolmogorov Smirnov yang didapatkan dari data penelitian ini, yaitu:

Tabel 5. Hasil Uji Normalitas

\begin{tabular}{lr}
\hline \multicolumn{2}{c}{ One-Sample Kolmogorov-Smirnov Test } \\
\hline \multicolumn{1}{c}{ Standardized Residual } \\
Test Statistic & 0,092 \\
Asymp. Sig. (2-tailed) & $\mathbf{0 , 0 5 4}{ }^{\mathbf{c}}$
\end{tabular}

$$
\text { Sumber : Data diolah, } 2021
$$

Tabel 5 memperlihatkan nilai Z yang diperoleh dari hasil output SPSS yaitu 0,092, sementara nilai signifikansinya yaitu 0,054 >0,05. Oleh karena itu, bisa dibuat kesimpulan sebaran data penelitian berdistribusi normal. 


\section{Hasil Uji Heterokedastisitas}

Pengujian ini memiliki tujuan guna melihat apakah ada ketidaksamaan (konstan) varian variabel pada suatu model regresi. Menurut Suliyanto (2011), suatu model regresi bisa dianggap baik jika model regresinya mempunyai gejala homoskedastisitas yakni varian variabel yang mempunyai kesamaan nilai (konstan) pada model regresinya. Dalam melakukan pendeteksian ada atau tidaknya heteroskedastisitas pada penelitian ini bisa dilaksanakan dengan pengujian Glejser. Dalam hal ini, uji heteroskedastisitas menggunakan pengujian Glejser dilaksanakan dengan melihat setiap variabel independennya mempunyai signifikansi > 0,05 (dengan dependen variabel yang sudah ditransform) maka model regresi tidak terkena gejala heteroskedastisitas (varian data homogen). Pengujian heteroskedastisitas yang dihasilkan dalam penelitian ini bisa dilihat di tabel dibawah:

Tabel 6 Hasil Uji Heterokedastisitas

\begin{tabular}{cc}
\hline Variabel & Sig. \\
\hline Partisipasi Masyarakat & 0,442 \\
Siskeudes & 0,443 \\
\hline
\end{tabular}

Sumber : Data diolah, 2021

Tabel 6 memperlihatkan semua variabel manajemen laba dan leverage memperlihatkan signifikansinya > 0,05 maka bisa dibuat kesimpulan tidak ada gejala heteroskedastisitas dalam model regresinya.

\section{Hasil Uji Multikolinearitas}

Pengujian ini memiliki tujuan guna menguji ada atau tidak adanya korelasi yang sempurna atau tinggi pada model regresi diantara variable independentnya. Suliyanto (2011) mengemukakan bahwa pada model regresi, apabila ada korelasi yang sempurna atau tinggi diantara variable independennya berarti model regresi tersebut dianggap telah terjadi multikolinearitas. Untuk memahami terjadinya multikolinearitas bisa diamati dari variance inflation factor (VIF) dan tolerance yang ada di setiap variabel, hasil pengolahan data dengan SPSS bisa diperhatikan di bawah ini:

Tabel 7 Hasil Uji Multikolinearitas

\begin{tabular}{lrc}
\hline & \multicolumn{2}{c}{ Collinearity Statistics } \\
\cline { 2 - 3 } \multicolumn{1}{c}{ Variabel } & Tolerance & VIF \\
\hline Partisipasi_M & 0,984 & 1.017 \\
Siskeudes & 0,984 & 1.017 \\
\hline
\end{tabular}

Sumber : Data diolah, 2021 
Tabel 7 memperlihatkan variabel independent (manajemen laba dan leverage mempunyai nilai VIF $<10$ dan tolerance $>0,1$, maka bisa dibuat kesimpulan data tersebut tidak ada multikolinearitas.

\section{d. Hasil Uji Regresi Linear Berganda}

Tabel 8 Hasil Uji Regresi Linear Berganda

\begin{tabular}{lcccc}
\hline Model & Koefisien & $\mathrm{t}$ & Sig. & \\
\hline (constant) & 2,974 & 3,877 & 0,000 & \\
Partisipasi Masyarakat & 0,101 & 2,218 & $0,029^{*}$ & \\
Siskeudes & 0,709 & 14,894 & $0,000^{*}$ & \\
$R$ Square & & & & 0,716 \\
Adjusted R Square & & & & 0,710 \\
F & & & & 112,190 \\
Sig. & & & & 0,000 \\
\hline
\end{tabular}

Sumber : Data diolah, 2021

Berdasarkan hasil olah data SPSS, didapatkan hasil persaman regresi yang dapat dilihat pada tabel 8 berikut :

$$
\begin{aligned}
& \text { Pengelolaan Dana Desa }=2,974+0,101 \text { (partisipasi masyarakat) } \\
& +0,709 \text { (siskeudes) }+\mathrm{e}
\end{aligned}
$$

Dari persamaan tersebut bisa diberikan penjelasan sebagai berikut:

a. Nilai konstanta regresi yaitu 2,974 bertanda positif mengartikan apabila seluruh variabel independen (partisipasi masyarakat dan siskeudes) diberikan asumsi konstan maka variabel pengelolaan dana desa akan mengalami kenaikan hingga 2,974.

b. Nilai koefisien regresi variabel (partisipasi masyarakat) yaitu 0,101 mengartikan tiap terjadi kenaikan 1 satuan pada variabel partisipasi masyarakat maka dapat menaikkan variabel pengelolaan dana desa hingga 0,101.

c. Nilai koefisien regresi variabel (siskeudes) yakni 0,709 mengartikan tiap terjadi peningkatan 1 satuan pada variabel siskeudes maka dapat menaikkan variabel pengelolaan dana desa hingga 0,709 .

\section{e. Hasil Uji t (Parsial)}

Menurut Ghozali (2011), pada dasarnya pengujian ini memperlihatkan jauhnya pengaruh suatu variabel independen secara individual guna mendeskripsikan variabel dependennya. Pada tabel 8 , bisa dibuat kesimpulan variabel partisipasi masyarakat nilai signifikansinya $0,029<0,05$ koefisien 0,101 sehingga bisa diartikan variabel partisipasi masyarakat berpengaruh positif dan signifikan terhadap pengelolaan dana desa 
dikarenakan nilai signifikansinya $<0,05$. Dari penjelasan tersebut, hipotesis pertama yaitu partisipasi masyarakat berpengaruh signifikan terhadap pengelolaan dana desa diterima.

Variabel siskeudes nilai signifikansinya $0,000<0,05$ dengan nilai koefisien 0,709 memiliki tanda positif. Sehingga bisa diartikan variabel siskeudes berpengaruh positif signifikan terhadap pengelolaan dana desa dikarenakan nilai signifikansinya $<0,05$. Dari penjelasan tersebut, hipotesis dua yaitu siskeudes berpengaruh positif terhadap pengelolaan dana desa diterima.

\section{f. Hasil Uji F (Simultan)}

Suliyanto (2011) mengemukakan pengujian ini memiliki tujuan guna memahami kesesuaian model atau goodness of fit. Pengujian ini dipergunakan guna memahami nilai prediksi yang bisa memberikan gambaran keadaan sebenarnya dengan nilai signifikansinya yaitu 5\%. Menurut Ghozali (2011) dasar pengambilan keputusan uji F dengan dua cara:

a. Dengan membandingkan $\mathrm{F}_{\text {hitung }}$ dan $\mathrm{F}_{\text {tabel }}$

Ho diterima jika $F_{\text {hitung }}<F_{\text {tabel }}$ pada $\alpha=5 \%$

Ho ditolak (Ha diterima) jika $\mathrm{F}_{\text {hitung }}>\mathrm{F}_{\text {tabel }}$ pada $\alpha=5 \%$ (good of fit)

b. Dengan berdasarkan angka signifikasi

Ho diterima jika angka signifikasinya $>0,05$

Ho ditolak (Ha diterima) jika angka signifikasinya $<0,05$ (good of fit)

Berdasarkan tabel 8, uji hipotesis didapatkan nilai Fhitung 112,190 dengan signifikansinya $0,000<0,05$. Sehingga bisa dibuat kesimpulan model persamaan regresi masuk dalam kriteria yang cocok ataupun fit.

\section{g. Uji Koefisien Determinasi (R2 )}

Pengujian ini memiliki tujuan guna mengukur seberapa besar kemampuan model guna memberikan penjelasan pada variasi variabel dependennya. Pada koefisien determinasi, nilainya ada diantara nol dan satu. Ghozali (2011) mengemukakan semakin kecilnya nilai R2 mengartikan bahwa kemampuan yang dimiliki variabel independen dalam menerangkan variabel dependennya sangatlah terbatas.

Pada tabel 8, diapatkan nilai Adjusted $R 2$ yaitu 0,710 atau $71 \%$, mengartikan variabel independen (partisipasi masyarakat dan siskeudes) berpengaruh terhadap pengelolaan dana desa sebesar $71 \%$, dan $29 \%$ lainnya dipengaruhi variabel lain yang tidak disebutkan pada penelitian ini. 


\section{Pembahasan}

\section{a. Pengaruh Variabel Partisipasi Masyarakat Terhadap Pengelolaan Keuangan Dana Desa}

Uji hipotesis pertama yang dihasilkan mengungkapkan partisipasi masyarakat berpengaruh positif terhadap pengelolaan dana desa, sehingga hipotesis pertama diterima. Hal ini dibuktikan dengan nilai signifikansi pada variabel partisipasi masyarakat sebesar $0,000<\alpha ́ \alpha 0,05$, yang menunjukkan bahwa variabel partisipasi masyarakat berpengaruh terhadap pengelolaan dana desa. Hal ini berarti bahwa partisipasi masyarakat merupakan salah satu faktor yang mempengaruhi pengelolaan dana desa yang artinya Hipotesis 1 Diterima.

Partisipasi masyarakat diperlukan untuk mewujudkan pembangunan desa yang sesuai dengan kebutuhan desa itu sendiri. Tanpa partisipasi masyarakat setiap kegiatan pembangunan akan gagal. Demikian juga halnya terkait dengan partisipasi masyarakat terhadap penggunaan dan pengelolaan dana desa, keterlibatan ini penting agar penggunaan dan pengelolaannya bisa lebih tepat sasaran dan manfaatnya akan lebih mengena dengan kepentingan riil dari masyarakat.

Partisipasi masyarakat sangat dibutuhkan untuk keberhasilan pembangunan di desa menuju ke arah yang lebih baik, peran dan kinerja pemerintahan desa juga sangat diharapkan untuk dapat menjalankan tugas pokok memimpin dan mengoordinasikan dalam melaksanakan urusan rumah tangga desa, melakukan pembinaan dan pembangunan masyarakat dan membina perekonomian desa. (Lomboh, 2015). Seperti yang dikatakan oleh Sekretaris Jenderal (SEKJEN) Kementerian Desa, Pembangunan Daerah Tertinggal, dan Transmigrasi (Kemendes PDTT) bahwa pengelolaan dana desa dilakukan secara transparan dan bertanggung jawab. keterlibatan masyarakat dalam proses perencanaan, pelaksanaan, hingga pengawasan program-program pembangunan desa menjadi kunci keberhasilan pengelolaan dana desa.

Hasil penelitian ini serupa dengan penelitian Julianto dan Dewi (2019) partisipasi masyarakat berpengaruh pengelolaan dana desa. Hasil dari penelitian ini dapat diambil kesimpulan bahwa partisipasi masyarakat dalam proses perencanaan, pelaksanaan, hingga pengawasan program-program pembangunan desa menjadi kunci keberhasilan dalam pengelolaan dana desa. 


\section{b. Pengaruh Variabel Siskeudes Terhadap pengelolaan dana desa.}

Uji hipotesis kedua yang dihasilkan mengungkapkan siskeudes berpengaruh positif terhadap pengelolaan dana desa, sehingga hipotesis kedua diterima. Hal ini dibuktikan dengan nilai signifikansi pada variabel partisipasi masyarakat sebesar $0,000<\alpha$ 0,05 , yang menunjukkan bahwa variabel siskeudes berpengaruh terhadap pengelolaan dana desa yang artinya bahwa pemberian dana ke desa yang begitu besar, jumlah pelaporan yang beragam dalam pengelolaan keuangan desa tentunya menuntut tanggung jawab yang besar pula oleh Aparat Pemerintah Desa yang artinya bahwa Hipotesis 2 Diterima.

Oleh karena itu Pemerintah Desa harus bisa menerapkan prinsip akuntabilitas dalam pengelolaan keuangan desa, dimana semua akhir kegiatan penyelenggaraan pemerintahan desa harus dapat dipertanggungjawabkan kepada masyarakat desa sesuai dengan ketentuan sehingga terwujud tata kelola pemerintahan desa yang baik (Good Village Governance). Untuk dapat menerapkan prinsip akuntabilitas tersebut, diperlukan berbagai sumber daya dan sarana pendukung, diantaranya sumber daya manusia yang kompeten serta dukungan sarana teknologi informasi yang memadai dan dapat diandalkan.

Sistem Keuangan Desa (Siskeudes) sangat diperlukan dalam pengelolaan keuangan pemerintahan desa. Keberadaannya membantu agar semua proses pembangunan, mulai dari perencanaan, pelaksanaan hingga evaluasi bisa dilaksanakan dengan baik. Dengan adanya siskeudes ini akan membantu pengelolaan keuangan dana desa secara transparan dan akuntabel, dengan penggunaan sistem keuangan desa yang baik akan mempermudah dan mempercepat dalam hal pencairan dana desa untuk periode selanjutnya karena sudah melaporkan realisasi periode sebelumnya secara tepat waktu.

Hasil penelitian ini serupa dengan pratiwi dan pravasanti (2019) menunjukkan bahwa siskeudes berpengaruh terhadap pengelolaan dana desa. Dengan adanya variabel siskeudes ini akan membantu pengelolaan keuangan dana desa secara transparan dan akuntabel.

\section{KESIMPULAN DAN SARAN}

Dari hasil pengujian maka didapatkan kesimpulan, yakni: (1)Partisipasi masyarakat berpengaruh positif terhadap pengelolaan dana desa. (2) Siskeudes berpengaruh positif terhadap pengelolaan dana desa. 
Berdasarkan kesimpulan di atas, maka peneliti memberikan saran sebagai berikut :

1. Bagi pemerintah desa, menjadi bahan pertimbangan guna melakukan partisipasi masyarakat dan penggunaan Siskeudes dalam meningkatkan keberhasilan pengelolaan dana desa serta pemerintah daerah tetap pada komitmen untuk meningkatkan keberhasilan pengelolaan dana desa sehingga pengelolaan dana desa akan lebih optimal dan dijadikan bahan pertimbangan keberhasilan yang maksimal.

2. Penelitian berikutnya diharapkan lebih mengembangkan variabel yang diteliti sebagai variabel pendukung yang mempengaruhi keberhasilan pengelolaan dana desa dan juga menambah indikator maupun daftar pertanyaan yang akan digunakan agar hasil penelitian yang diperoleh dapat lebih baik. Selain itu, diharapkan pula dapat memperluas responden dan ruang lingkup penelitian agar lebih dapat digeneralisasi.

\section{DAFTAR PUSTAKA}

Adi. 2013. Implementasi Pengelolaan dan Penatausahaan Keuangan Desa Berdasarkan Perda Nomor 16 Tahun 2007 Tentang Keuangan Desa Mulawarman Kecamatan Tenggarong Seberang Kabupaten Kutai Kartanegara.

Atmadja, T. Saputra, Kak. Koswara, MK. 2018. The Influence Of Village Conflict, Village Apparatus Ability, Village Facilitator Competency And Commitment Of Local Government On The Succes. Academy of Accounting and Financial Studies Journal. Volume 22, Number 1.

Ghozali. 2011. Aplikasi Analisis Multivariat Dengan Program SPSS. Semarang: BP Undip.

Tahawa, Taufik Hidayat B dan Riady Ibnu Khaldun. 2021. Hubungan Tingkat Kemampuan Keuangan Daerah Dan Persentase Kemiskinan Pada Pertumbuhan Ekonomi Provinsi Sulawesi Barat Tahun 2013 - Tahun 2018. Journal of Economic, Public, and Accounting (JEPA).Vol. 3 No.2.

Isbandi Rukminto Adi. 2007. Perencanaan Partisipatoris Berbasis Aset Komunitas: dari Pemikiran Menuju Penerapan. Depok: FISIP UI Press.

Julianto, I Putu dan Dewi, Gusti Ayu Ketut Rencana Sari. 2019. Pengaruh Partisipasi Masyarakat, Penggunaan Sistem Keuangan Desa, Kompetensi Pendamping Desa Serta Komitmen Pemerintah Daerah Terhadap Keberhasilan Pengelolaan Dana Desa. Universitas Pendidikan Ganesha, Jalan Udayana No. 11, Singaraja, Bali, Indonesia. Jurnal Ilmiah Akuntansi -Vol. 4, No. 1, Hal: 24-42 .

Lomboh, Arthur T. 2015. Partisipasi Masyarakat Dalam Pembangunan Di Desa Lesabe Kecamatan Tabukan Selatan Kabupaten Kepulauan Sangihe. Diunduh dari https://media.neliti.com/media/publications/1091-ID-partisipasi-masyarakat-dalampembangunan-di-desa-lesabe-kecamatan-tabukan-selata.pdf 
Mulyanto. 2015. Law enforcement. No.6 Year 2014 about villages in bali in perspective of legal sociology. Dissertation, Faculty of Law UGM

Pratiwi, Desy Nur dan Pravasanti, Yuwita Ariessa. 2020. Analisis Penggunaan Siskeudes dalam Pengelolaan Dana Desa. STIE AAS Surakarta, Indonesia. Jurnal Akuntansi dan Pajak, 20(2), 2020, 217-223 http://jurnal.stie-aas.ac.id/index.php/jap

Suliyanto. 2011. Ekonomika Terapan: Teori dan Aplikasi dengan SPSS. Andi Offset. Yogyakarta. 